\title{
Police Scotland: challenging the current democratic deficit in police governance and public accountability
}

\author{
Barry Loveday ${ }^{1}$
}

Published online: 29 May 2018

(C) The Author(s) 2018

\begin{abstract}
This article considers the recent creation of Police Scotland and the substitution of local police forces for a national police service 'Police Scotland' in 2013. It assesses the drivers for change and the arguments presented by both politicians and police professionals in favour of the eradication of all 8 local Scottish forces and the creation of a single police force. It contrasts developments in Scotland with those in England and Wales where there has been a recommitment to local delivery of police services in which local police boundaries have been retained with the introduction of Police and Crime Commissioners. It considers the police boundaries and coterminosity with local authorities and highlights the absence of shared boundaries within Police Scotland. It reflects on the removal of local accountability in Scotland with the abolition of Police Boards and the creation of a national and unelected Scottish Police Authority. It highlights the significance of police planning led by senior officers from Strathclyde Police and the impact of this on Police Scotland. It raises legitimate questions as to the overall efficacy of a national force made answerable to a nationally appointed body, the Scottish Police Authority. Finally, it makes a number of recommendations which might go towards someway to reestablishing a degree of local accountability to communities and local governments in Scotland which is now so clearly absent.
\end{abstract}

Keywords Centralisation · Police planning - Accountability failures · Partnerships and shared police boundaries $\cdot$ Police boards and public engagement

Barry Loveday

barry.loveday@port.ac.uk

1 Reader in Criminal Justice Administration, ICJS, St George's Building, University

of Portsmouth, Portsmouth, UK 


\section{Introduction}

As has been noted by academic researchers, there has been in recent years a remarkable divergence within the UK in terms of the approach to reforming police structures (Fyfe and Scott 2013). In Scotland, the decision was taken by the Scottish National Party (SNP) to move to a single service for the whole country which in a relatively short period of time led to the amalgamation of the remaining eight police forces in Scotland to form Police Scotland (Fyfe and Scott 2013: 121). This was to involve a decisive break with history and tradition in Scottish police administration (Fyfe and Scott 2013: 119).

Most notably this also involved the complete removal of any effective local authority role in police service delivery, the immediate result of the abolition of local Police Boards. These had, until the arrival of Police Scotland, exercised some influence over local policing while also providing limited funding and calling the police to account. The latter responsibilities were, instead, to be relocated to the national level. This reflected, as has been argued by observers, a decisive move to centralising policing and was fully intended to represent a clear break from the past (Fyfe and Scott 2013: 120).

Interestingly and in complete contrast to the Scottish experience, a decision was taken south of the border to move in the opposite direction. In England and Wales, the Police Reform and Social Responsibility Act (2011) was designed to significantly strengthen local police service delivery while also distinctly enhancing police accountability (Loveday 2013a, b: 106). The abolition of police authorities and the introduction of directly elected Police and Crime Commissioners (PCCs) appears to have achieved, in the main, the political objectives set for them (Loveday 2015a, b: 115). Although still a relatively new development, it is clear that PCCs have been able to rebalance the relationship between police chiefs and elected officials (Loveday 2015a, b: 116).

This has been in part reflected in the remarkable increase in the turnover of chief officers. PCCs have exercised, as demonstrated in the case of the chief constable of Avon and Somerset in 2015, their considerable powers in terms of hiring and requesting the resignation of chief officers. This may also be one consequence of the decision of the Home Office to no longer closely engage with local policing which is now considered to be the sole responsibility of chief officers and PCCs. This direction of travel, away from increasing centralisation, is set to increase as many big cities have opted to introduce directly elected mayors who can be expected ultimately to take over responsibility for the local police force. It is, however, balanced by a view from the centre that the National Crime Agency (NCA) which is directly accountable to the Home Secretary could be expected to take on a much wider remit and which will at some point include counter-terrorism and all serious-organised crime, on a national basis (Loveday 2013a, b: 100). The NCA role is intended to take pressure off local forces so that they no longer will be expected to exercise a multi-functional role.

However, it is noticeable that the Home Secretary has had to confront consistent pressure from police associations to introduce police force amalgamations to 
create either large regional forces or a national police force. Most recently, this was to be demonstrated within the Steven's Report 'Policing for a Better Britain' (2013) which recommended the abolition of PCCs and the creation of Regional Police Boards. It is a matter of interest that Theresa May as Home Secretary refused to accede to this professional police objective. At a PSAEW annual conference in 2015, she was indeed, in defence of the new police governance in England and Wales, to cite Police Scotland as an example of what could go wrong. This demonstrated, she argued, that such restructuring was potentially regressive in that it did not generate the savings claimed for it but did serve to undermine local accountability (Hickey 2015).

\section{Drivers for change}

The observations of the then Home Secretary are of interest. A central argument for the introduction of a national police force was to be based on the likelihood of substantial cuts to police funding and the need to make savings while at the same time protecting police establishment. Indeed, the then Chief Constable of Strathclyde was to publicly state that a national police force would protect police numbers as a result of saving made on infrastructure (Fyfe and Scott 2013: 126).

Subsequently the Scottish Government's Outline Business Case (OBC) was to claim that a national structure would lead to savings of $£ 100$ million a year while also protecting the 'magic number' of 17,234 police officers (Fyfe and Scott 2013: 126). To date no police restructuring exercise has, in the event, been able to clearly demonstrate major savings of the nature and size of that claimed for Police Scotland (Loveday 2006: 12). More significantly perhaps, the determination to protect police numbers has long ceased to have any traction south of the border either. This is the consequence of a growing recognition that it is not police establishment but deployment of personnel which remains the crucial factor in terms of determining police effectiveness (Bayley 1994: 4).

As has been found in England and Wales, for example, the steady and significant fall in acquisitive crime has occurred against a background of declining rather than increasing police numbers (Loveday 2015a, b: 123). Moreover, the incremental nature of the growth of police establishment has also proved to be problematic. This was based on an (untested) assumption that more police could be expected to impact on the crime rate. Yet, the underlying problem as to what might be either the maximum or minimum number of police officers needed to provide effective policing was never really addressed and remains largely unanswered (Loveday 2006: 328).

It also appears to be the case that, rather unusually, in Scotland professional opinion as to the value of a national force proved to be divided. Many chief constables heading up the threatened 8 forces did not share the optimism of either the SNP or fellow chief constable of Strathclyde as to the benefits of amalgamation. They argued instead for a regional structure to allow for local demands and local differences. In the event, concerns expressed by these officers were to prove to be fully justified as the 'new model' police force was to make no allowance for differing regional or local interests and priorities. 


\section{Planning a new police structure}

Initially planning for the reformed police service was to be the responsibility of the Scottish Government. However, in 2011 this was to be devolved to the Scottish Police College where the Sustainable Policing Project Team was located. The Team was to be led by a senior police officer, Neil Richardson, who at this time was also Deputy Chief Constable of Strathclyde Police (Fyfe and Scott 2013: 125). As a result, the reform process was to be largely controlled by the police and I shall argue that this was to prove to be a significant factor in its ultimate failure.

Thus two elements were to be exhibited within the project which should have exercised the minds of political observers. First, the plans arising from the project appeared to demonstrate a traditional police objective which has been, where possible, to remove their service from effective local oversight and accountability (Reiner 2010: 227). This has been a long-term feature of police interpretations of effective policing. Based on a 'Professional Policing Model', it has, as its objective, a significant enhancement of police operational autonomy (Reiner 2010: 227).

This feature of 'police governance' is not, of course, confined to Scotland. Most recently, the Independent Steven's Independent Commission on policing and future police governance in England and Wales was to recommend the immediate abolition of PCCs, the creation of large regional police forces and the creation of Police Boards consisting of indirectly elected councillors. As an example of the search for police hegemony, these proposals were difficult to beat (Stevens 2013). They did have, however, all the hallmarks of the 'professional policing' approach. If implemented, these proposals would have served to resurrect chief officer autonomy while strengthening police operational independence (Loveday 2013b).

In Scotland, this outcome was to be achieved by way of the abolition of local Police Boards and the absence of any local accountability mechanism within the new structure. The identification of local commanders for the 32 district authorities might be seen, at best, as a kind of tokenism to the locality as does the requirement for both parties to agree a local 'policing plan', the significance and status of which remains quite uncertain. Thus, for example, under the new model, central direction from the chief constable, on 'operational policing grounds' can be expected to override any previously agreed local commitments. As a consequence of that, local 'accountability' to the districts might be best described as being symbolic rather than real. Moreover, the police structure developed by the Project Team also ensured that there would be no shared boundaries between police and the districts. Thus, below the central command, 14 police divisions were established which ensured there could be no coterminous boundaries between police divisions and the 32 local districts (Fyfe 2014).

\section{Experience of police and community partnerships}

This approach provides a clear contrast with police structures south of the border. Since the introduction of the Crime and Disorder Act in 1998 police forces have been encouraged to create coterminous boundaries between police Basic Command 
Units and local district and unitary authorities. Although recent financial demands have placed pressure on this arrangement, the primary aim has been to create a closer relationship between local government and the police. The move towards coterminous boundaries was interestingly to be given explicit support by the Police Superintendents Association (PSAEW 2005).

\section{Police perceptions of the value of local partnerships}

In a far-sighted document produced by this association, it was to be argued that the single most important factor determining the effectiveness of the BCU was establishing shared boundaries (PSAEW 2005). This was because it was recognised that effective policing could be better achieved through partnerships with other agencies, most notably if not exclusively, with local authorities (Loveday 2007). Such was its commitment to partnerships the PSAEW was, at this time, to also recommend that the local authority should be involved in the selection of the local police commander (PSAEW 2005).

Surveys of local commanders undertaken in 2002 to identify the greatest pressures facing them in terms of demand on police resources demonstrated why a partnership approach made sense. The responses of local commanders (police superintendents) indicated that while gun crime, organised and violent crime did not loom large in terms of their incidence in the BCU area, other problems certainly did. These, however, were linked overwhelmingly to ASB-related incidents and alcoholdriven antisocial behaviour (Loveday and McClory 2007). Local police commanders were swamped with problems associated with excessive alcohol use and alcoholrelated disorder. A second survey undertaken in 2007 was to replicate these findings and fully supported the PSAEW position that partnership arrangements with other agencies could be seen as being a central element to any effective response to the problem (Loveday and McClory 2007).

In the absence of any similar survey undertaken in Scotland, it is difficult to make any clear comparisons. There must, however, be an assumption that outside of the largest conurbations the threat of violent crime is likely to be overshadowed by similar low level but very frequent ASB- and alcohol-related incidents. This matter does go beyond the determination of types of crime dealt with by police forces. It is now acknowledged that the problem of public fear of crime has as much, if not more, to do with antisocial behaviour as it ever does with 'crime'. Trying to impact on ASB can be viewed, as a result, as providing a major priority for police services throughout the UK (HMIC 2010; Loveday and McClory 2007).

It is of interest to also recognise that while the PSAEW was to highlight the reality of demands on police managers, elsewhere the police organisational culture continued to attach an overwhelming importance to violent crime, organised crime and gun crime. As long ago as 1990 within the Operational Policing Review of that year, it had become evident that these police priorities did not match those of the public (OPR Joint Consultative Committee 1990).

Public priorities proved to be much more prosaic relating as they did to ASB, dog fouling and young people using public space (OPR 1990). The latter did not exactly 
capture the imagination of police professionals. Yet the major purpose of police reform south of the border has been a rather belated attempt to match up police priorities with those of the public. It has been concluded that as tax payers the public has a clear right, after all, to help determine current and future police priorities.

\section{The role and influence of Strathclyde police}

A further driver for change emanated from the largest police force in Scotland. Strathclyde Police, led by a Chief Constable committed to a national force, (and also perhaps an expectation that he might lead it), has had, since regionalisation, within even the world of policing a somewhat aggressive image (Fyfe 2014). This went back to the early amalgamations of the 1970 s which led to the creation of 8 police forces within which Strathclyde with over 7000 police officers was far and away the largest force with the highest density of population (Davidson et al. 2016).

As has been argued, the push for regional or national police structures in Scotland has a long history (Davidson et al. 2016). As long ago as 1966, a motion was to be passed at that year's annual Scottish Police Federation conference in favour of nationalising policing in Scotland. Later experience of regionalisation, however, was to lead to a rejection by the Federation of any further amalgamations. This reaction arose particularly sharply in the Strathclyde region, where the police force embraced the urban conurbations of Clydeside, the mining areas of Lanarkshire and also the rural areas of Argyllshire and the islands (Davidson et al. 2016).

As was to be argued by the first Chief Constable of the region, David McNee, there were clear tensions between the need for 'standardisation and that of flexibility' (Davidson et al. 2016). Experience of Strathclyde was to result by 1976 in the Police Federation ending its support for the creation of a single Scottish service. It was reported that the Federation Secretary had stated that this could be expected to be 'an even greater disaster than regionalisation has proven to be' and that 'it was very hard to police an area like Mull and have the same policy in the East End of Glasgow' (Davidson et al. 2016). As the same authors note in relation to this experience:

Arguably, the matter was not helped by the decisions that were made to roll out what had been the Glasgow City model across the new Strathclyde policing area (Davidson et al. 2016).

As has been argued, Glasgow's City Police were always subject to greater internal structural and procedural change than elsewhere. This was to mean that when the city's working practices were implemented across the region, change was to prove much greater than ever experienced in the more rural regional forces. Not for nothing was the new Strathclyde Police region to be dubbed by many officers as 'StrathGlasgow' (Davidson et al. 2016). This experience has an immediate application for the introduction of Police Scotland. Thus, the same 'Strath-Glasgow' model imposed in that region has now in effect been expanded to include the whole of Scotland. Interestingly, in this context, the same authors note of the roll-out of the Strath-Glasgow model that: 
Interviews do suggest that the introduction of any new policing model needs to be sufficiently flexible to recognise differences in local cultures and local needs whatever the larger structures, labels or identities that are formally set in place (Davidson et al. 2016).

Some evidence of the impact of the roll-out of Strathclyde Police practices to the rest of Scotland has been provided by a local observer, who as secretary to the Federation's northern branch formerly served in the scrapped Northern Constabulary. He has noted how a significant change in operational policing took place 'on the basis of a few lines in a very large document' and stated that he was opposed to the idea that 'armed response officers were being deployed to deal with routine incidents' He added that:

At no stage did anyone envisage that the consequence of that would be officers walking about with pistols strapped to them at fetes and charity events. That is a significant change and the unwillingness to accept the sensitivities that provoked showed a disregard for the community I represent and was also illjudged about what is required (Police Oracle 2015a).

A similar problem was to be experienced in relation to recent use, by Police Scotland, of stop and search powers. It was to be discovered following the roll-out of Police Scotland that 'police carrying guns used stop and search 8000 times in just 1 year' and that this represented 150 searches being conducted every week by officers carrying guns on routine duties'. Although the chief constable later removed all armed officers from routine duties, it was argued that at any moment, without notice and without consultation, 'the decision could be reversed' and that this was known 'because that was what had happened before' (Police Oracle ibid 2015b).

Unfortunate incidents involving a death in police custody and an undetected road accident on the M9 only appeared to further highlight problems surrounding a more centralised police system where saving appeared to have been achieved by the closure of local police call centres. It led to a former politician to claim that Police Scotland had proved to be 'one of the worst performing police forces in history'. The same spokesman was to add that it was unlikely that the appointment of either a new chief constable or chair of the Scottish Police Authority would be sufficient to address the depth of the problems 'stemming from over-centralisation' (Police Oracle 2015c).

\section{Responding to the problem}

Although contested by the Scottish Government, which remains wedded to the current structure of Police Scotland, it is apparent that this model has significant flaws. Not the least of these is the complete removal locally of any community involvement into policing the immediate result of the abolition of the Police Boards. The problem has been compounded by the decision to establish a national police authority, the SPA, whose membership was to be based on appointment rather than election. Indeed, this development only offers a further contrast to those implemented south 
of the border where direct election, for better or worse, has now assumed an ever greater significance (Mawby and Smith 2013).

\section{The Scottish police authority}

In addition to this, the SPA has exercised the limited powers accorded to it with considerable caution. In doing so, it appears to have only replicated the experience of police authorities in England and Wales (Reiner 2010: 228). One way forward in resolving the problem of SPA membership could therefore be to revise the criteria for membership. Given the role which it has been given (although perhaps failing to exercise), it could in future consist of members drawn from each of the local districts. While a membership of 32 councillors might be unwieldy, it would, at least, provide greater legitimacy while providing an effective channel for local representation.

\section{Need for decentralisation}

The need for further internal reform has indeed been recently recognised in order to heighten the SPA's legitimacy and relevance (Malik 2017). However, the absence of local district representation remains a matter of concern. As a result, local District engagement by way of membership of the SPA may offer the best way forward and would be a significant addition to just agreeing a local policing plan, which remains of doubtful value, at district level.

Some form of devolution it is argued is now clearly necessary. This might also go beyond 'regionalisation' to re-engage local communities. However, it remains of interest that in the referendum conducted in June 2011 it was to be discovered how limited the appeal of a national police force was to the public 'with most respondents preferring a regional structure' (Fyfe and Scott 2013: 126). A case has already been made for the creation of four 'regional force areas' with quasi-autonomous powers which could be established under the overall control of one chief constable in order to 'decentralise policing' (Police Oracle 2015c).

\section{Failure of police leadership}

An admission of the degree of failure of the current national model has in fact already been made by the Scottish Government's First Minister. In a recent announcement Nicola Sturgeon has stated that, following the early departure of Stephen House the next chief constable would be required to face what were to be described as 'local accountability panels' in response to the evident democratic deficit occasioned by the introduction of Police Scotland (Police Oracle 2015d). Sadly his successor as chief constable of Police Scotland, Phil Gormley, has already been placed on 'special leave' and will not, after all, be able to fulfil those requirements.

It might be argued therefore that if local accountability panels are to be the future vehicle of accountability there is a case for either re-establishing the local Police 
Boards or giving the proposed panels the powers exercised earlier by these bodies. In their absence, the panels could become little more than talking shops. They need to have some authority and that is only derived from the exercise of budgetary (and other) powers. As argued by the leader of the Scottish Liberal Democrats in response to the growing crisis surrounding operational policing undertaken by Police Scotland:

A police force with no democracy is no police force for a democracy and the relationship between communities and police need to be strengthened (Police Oracle 2015b).

\section{Identifying the value of local policing}

The same spokesman might also have added that the relationship of the police to the community remains a vital element in sustaining the overall effectiveness of the police. This is because the police remain overwhelmingly dependent on information being given to them by the communities they police. It is this feature of policing rather than police specialisation that largely dictates police performance. This dependency is perhaps best summarised by Reiner who has noted that:

The major findings of studies of the process by which crimes are cleared up is that the prime determinant of success is information immediately provided by members of the public (usually the victim) to patrol officers or detectives when they arrive at the scene of the crime. If adequate information is provided to identify the culprit fairly accurately the crime will be resolved; if not, it is almost certain not to be (Reiner 2010: 119-200).

The need for good community links to generate information which can be of value to the police has most recently been again emphasised against the background of potential terrorist activity. Commenting on the fact that in Paris the Police National has never sought to establish a community dialogue with ethnic communities, one police officer was to state that in France, 'Police do police work and it is not my job to play football with the kids in the communities' (Connett and Forrester 2015). It may have been that failure which demonstrated the limitations of this approach. It may also explain why the Paris terrorist attack proved to be such a surprise to the police.

In London, the situation may well be different not least because of the level of intelligence collected by PCSOs deployed in many of the potentially most problematic communities. It has been recently argued that PCSO intelligence now provides the basis within the MPS for its daily intelligence briefings, and these are delivered to response and proactive police units across London (Loveday and Smith 2014). Here, the diverse backgrounds of PCSOs and their ready availability for visible patrol appear to significantly add to their intelligence function.

Encouraging community engagement may well provide a greater advantage over investment in police specialisms. Specialisation has, by way of high abstraction rates, served to remove ever greater numbers of warranted officers from general policing and patrol activity. Specialisation can therefore come at a potential cost in 
terms of community relations (Loveday 2007: 14). Yet, a recent defence of Police Scotland has proved to be its ability to support greater specialisation. Thus, the Scottish Government has argued that a single service had both removed artificial barriers of previous force areas and a major benefit was seen to be to 'provide better access to specialist services and equipment than ever before' (Police Oracle 2015c). Whether this gain matches the loss of both local identity and contact with the community might be contested.

\section{Organisational change}

Further restructuring could be potentially destabilising. Yet the extreme nature and extent of the organisational dysfunction exhibited by Police Scotland requires further consideration in terms of how, in future, police services might be better delivered. Evidence suggests that local police forces are best able to provide both local visible policing and reassurance to communities (Loveday and Reid 2003). A strong commitment to local delivery of service should therefore become the guiding light of any further organisational change.

If a national police system is to be retained, it should be balanced by structures that reinforce both local delivery and local accountability. This could be made the joint responsibility of the PSA and local districts. The latter should also be given a role in local police finance by reintroducing a police precept, being involved in the choice of local commander and additionally a role in responding to public complaints against the police. Most of these responsibilities have been accorded to PCCs in England and Wales while a number have already expanded their role to include engagement within the complaints process. The importance of transparency in the complaints process was recognised by Theresa May when Home Secretary when she agreed to public hearings in police complaints cases. This may serve to challenge an organisational culture that can encourage both professional dominance and a degree of opacity which might be seen as quite foreign to any advanced European democracy (Reiner 2010: 216).

\section{Convention of constabulary independence}

It may now also be appropriate to begin challenge the convention of constabulary independence or, at least, how this is interpreted within the police service. At its most basic operational independence should mean that no politician is able to tell the police who they should arrest. Thereafter, the convention may need clarification. This is because the police service has over the recent past sought to expand its remit to the extent that any effective oversight has proved difficult to sustain (Loveday and Reid 2003). The lack of oversight has within some police forces had unfortunate consequences as exampled by South Yorkshire Police and the Hillsborough disaster (Loveday 2012).

There is a clear need to engage with the police force and this is, in England and Wales, now being actively encouraged by the Home Secretary. The convention of constabulary independence has been, however, most recently subject to review by 
the English courts. In a recent case involving the former chief constable of South Yorkshire, the Court of Appeal was to find that the Police Reform and Social Responsibility Act 2011 in giving the PCC wide powers, overrode earlier protections provided by the 1964 Police Act and the Blackburn case to chief officers (see Regina -v- South Yorkshire PCC 2017).

A similar reorientation and engagement might be of value within the Scottish context. This is because much of what the police do (and don't do) is and will remain highly political. It is therefore entirely appropriate that decisions over police priorities and initiatives should be the subject of debate and contested when necessary. Moreover, the police service should no longer be able to evade public challenges by reference to the convention of constabulary independence. Recent experience of both the attitude and behaviour of the first Chief Constable of Police Scotland to his public duty of accountability to government bodies suggests there might be a ready agreement with this within both the political and public arena.

It remains the case that traditionally within the Scottish experience of policing there has been, in the past, a clear commitment to local democratic control of the police. As has been argued in relation to the Royal Burghs in the twentieth century, there was a strong sense of civic pride and identity that was expressed through the 'rhetoric of democracy in which it was argued that local police forces should be accountable to local people' (Davidson et al. 2016). As the same researchers suggest:

Sense of community was associated with local autonomy in opposition to the centralising state and was articulated through a sense of place. Moreover local meant 'civic'. These beliefs, which were cultural and political, remained pretty much intact until the early 1960s. Supporters of amalgamation tended to make arguments that, in contrast, were financial and logistical (Davidson et al. 2016).

Interestingly, many of those observers of the move to full amalgamation were to later declare that while they did not know of very many advocates of the single service- 'it had proved to be a financial imperative which had driven it' (Police Oracle 2015c). The threat of financial cuts and a questionable defence by way of police establishment were indeed major drivers for Police Scotland. Together, these constituted the burial party for the last vestiges of local civic responsibility for the police service in Scotland. This has been, on balance, a singularly high price to pay for questionable efficiency savings and police specialisation upon which the argument for Police Scotland was to be based and, thereafter, defended.

\section{Need for further restructuring}

It is apparent that in relation to Police Scotland defending the current structure is not an option. There is a need to address the gaping democratic deficit created by the national police model which has effectively eradicated both local engagement and the accountability of the police. As a result, some structural reform 
will be needed and while politically it may prove difficult to admit to open failure it is clear that in the case of Police Scotland, further 'fine tuning' might be entirely appropriate.

How this takes shape will be the subject of debate but the problem of overcentralisation of power occasioned by the creation of Police Scotland should be addressed. If this structure remains in place then strong local counterbalancing bodies should be contemplated. This is, however, never likely to be achieved by way of local 'accountability panels' proposed earlier by the First Minister.

A much more stable and meaningful basis for accountability will need to be created if local public opinion is to be satisfied. This could take the form of the resurrection of local Police Panels by each of the districts. They should work in partnership with other local services and be based on shared local boundaries. They should also be given a statutory responsibility for determining local police priorities and ensuring that local interests are not overridden by the Chief Constable. Powers given to these bodies might include joint appointments of local commanders and some budgetary responsibilities. To entrench the element of local engagement, some thought might be given to replicating developments south of the border where elected authorities take up a more meaningful role in dealing with public complaints against the police.

\section{The case for a regional tier of policing}

It is also evident that given Scotland's differing demography an intermediate regional police structure will need to be put in place. While localism and local delivery of policing is to be always preferred, it is clear that a regional tier of service delivery is needed. Here, the number of regional police commands deemed to be appropriate would be subject to both public and professional debate. However, it would appear that the earlier concerns expressed by members of ACPOS prior to the creation of Police Scotland have proved to be entirely justified. As they argued, the absence of a regional tier of policing has indeed placed far too much responsibility on the shoulders of a remote central command structure (Fyfe 2014).

There should be a regional police command which would have the responsibility for providing a platform for all strategic, blue light, emergency and other specialist services within the region. The logic of this proposal would be that a regional structure could be best able to reflect the different characteristics and demands that are reflected in a country the size of Scotland and which exhibits such differing social, economic and cultural characteristics.

Additionally, the 14 police divisions might benefit from further review. Here, the purpose would be to either reduce their number to conform to the proposed regional commands or to increase them to begin to establish coterminous boundaries with local authorities and upon which community safety partnerships might also be created. This would be a potentially challenging exercise. However, in terms of delivering joined up service delivery at local level, it could well repay further investigation. 


\section{Strengthening the representational base of the SPA}

Finally at national level, it is also apparent that significant reform is needed. This would initially involve the SPA itself. There must be some concern that the authority made responsible for holding the chief constable of police to account has itself, no claim to either democratic legitimacy or elected authority. Earlier experience of police authorities across the Border suggests that many often fail to exercise the limited powers they hold. As a vehicle for encouraging effective accountability, they proved to be highly flawed (Reiner 2010: 227). This feature of the police authority may have been replicated by the SPA.

Given this serious limitation, it might be of value to fully explore the significantly greater powers given to Police and Crime Commissioners in England and Wales. They are of a nature and extent that transcends any powers given to police authorities in the past. As has been argued by one PCC, the power of general competence given to PCCs within the 2011 Police reform and Social Responsibility Act meant that elected PCCs 'could in effect do anything that was lawful'. It is also significant that PCCs have been given responsibility for crime in their force areas. This has proved to be important in widening the remit of the PCC which goes well beyond that of accounting for only 'policing' (Hayes 2013).

\section{Conclusion}

Widening the powers of the SPA in line with those of PCCs to include responsibility for crime would be of value as indeed might be introduction of direct election to that authority. However, in the absence of direct elections then representation by indirect election should form the basis of a reformed SPA. Here, the future membership of the SPA might consist of representatives drawn from the 32 districts. This would, at least, provide a real channel of communication for locally elected representatives who would be able to hold the chief constable to greater if not immediate account. It might also begin to address the significant democratic deficit occasioned by the creation of Police Scotland.

Open Access This article is distributed under the terms of the Creative Commons Attribution 4.0 International License (http://creativecommons.org/licenses/by/4.0/), which permits unrestricted use, distribution, and reproduction in any medium, provided you give appropriate credit to the original author(s) and the source, provide a link to the Creative Commons license, and indicate if changes were made.

\section{References}

Bayley, D. 1994. Police for the Future. Oxford: OUP.

Connet, D, and D. Forrester. 2015 British police trusts in its work on the ground. The Independent on Sunday. 
Davidson, N., A. Jackson, and D. Smale. 2016. Police amalgamation and reform in Scotland: The long twentieth century. The Scottish Historical Review XCV2: 241.

Fyfe, N 2014. If 8 forces was the problem why was Police Scotland the solution, how did we get there and what difference has it made? In SIPR Presentation to the Police Foundation Oxford Policy Forum, All Souls College Oxford.

Fyfe, N., and K. Scott. 2013. In search of sustainable policing? Creating a national police force in Scotland. In Centralising Forces: Comparative Perspectives on Contemporary Police Reform, ed. N. Fyfe, J. Terpestra, and P. Tops. The Hague: Eleven International Publishing.

Hayes, S. 2013. Interview with Simon Hayes PCC Hampshire and Isle of Wight. Staple Gardens, Winchester: OPCC.

Hickey, H 2015 Police Scotland problems should be a warning over restructure, urges Home Secretary. Police Oracle 9th September.

HMIC. 2010. Anti-Social Behaviour: Stop the Rot. London: Home Office.

Loveday, B. 2006. Size Isn't everything restructuring policing in England and wales. London: Policy Exchange.

Loveday, B. 2007. Basic command units and local authorities: Future mechanisms for police accountability and service delivery. International Journal of Police Science and Management 19(4): 324.

Loveday, B. 2013a. Commentary. The Police Journal 86(2): 97.

Loveday, B. 2013b. In Centralising Forces Comparative perspectives on Contemporary Police Reform in Northern and Western Europe, ed. R. Fyfe, J. Terpestra, and P. Tops. The Hague: Eleven International Publishing.

Loveday, B. 2015a. Police management and workforce reform in a period of austerity. In Police Services Leadership and Management Perspectives, ed. P. Wankhade and D. Weir. London: Springer.

Loveday, B. 2015b. Plodding along: Police personnel configuration needs urgent reform, Policinginsight CoPacc, 20th November.

Loveday, B., and A. Reid. 2003. Going Local. Who should run Britain's Police?. London: Policy Exchange.

Loveday, B., and J. McClory. 2007. Fitting the Bill. London: Policy Exchange.

Loveday, B., and R. Smith. 2014. A critical evaluation of current and future roles of PCSOs and neighbourhood wardens in the MPS and London Boroughs. International Journal of Police Science and Management 17: 74.

Malik, A. 2017. Steering from the Centre: The SPA and police governance in Scotland. SIPR Research Summary No 28.

Mawby, R., and K. Smith. 2013. Accounting for the police: The new police and crime commissioners in England and Wales. The Police Journal 86(2): 143.

Operational Policing Review. 1990. Joint Consultative Committee, Surbiton Surrey.

Police Superintendents Association of England and Wales. 2005 Moving Policing Forward, Pangbourne Berkshire.

Policy Exchange. 2007. Fitting the Bill, Local policing for the 21st Century, London.

Police Oracle. 2015a. The former nationalist ex-fed rep who says everything in policing should be about the local, Police Oracle 20th November.

Police Oracle. 2015b. We need to spell out chief constable's power, Police Oracle 27th November.

Police Oracle. 2015c. Call to break up national force rejected, Police Oracle 21st August.

Police Oracle. 2015d. First Minister: Chief constable can't be a law unto himself, Police Oracle, 5th April 2015.

Regina -v- South Yorkshire PCC, QBD 2017.

Reiner R. 2010. The Politics of the Police OUP, 4th Edition.

Stevens J. 2013. Report of the independent commission, policing for a better Britain, London. 